\author{
CHRISTOPHER NIKULIN*, ANDRES ULLOA**, CARLOS CARMONA**, \\ WERNER CREIXELL***
}

\title{
A COMPUTER-AIDED APPLICATION FOR MODELING AND MONITORING OPERATIONAL AND MAINTENANCE INFORMATION IN MINING TRUCKS
}

\section{WSPOMAGANY KOMPUTEROWO PROGRAM DO MODELOWANIA I MONITORINGU INFORMACJI DOTYCZĄCYCH PRACY I SERWISOWANIA GÓRNICZYCH POJAZDÓW}

\begin{abstract}
The combination of maintenance planning and key performance indicators are relevant to create a more holistic scenario of the mining activities. On the one hand, reliability and maintainability are system characteristics suitable for planning maintenance strategies. On the other hand, key performance indicators are suitable to analyze cost and resource consumption information about mining equipment. Nevertheless in practice, both approaches are modeled separately and frequently by different team-works of a mining company. With this in mind, a computer-aided application was conceived to drive with better efficacy the operational and maintenance strategy in a complex process where the equipment is in continuous movement such as the transportation process in an open-mine pit.
\end{abstract}

Keywords: Reliability, Maintainability, Computer-aided application

Połączenie planowania eksploatacji i działań zabezpieczających i analizy głównych wskaźników wydajności stanowi podstawę opracowania holistycznego scenariusza prowadzenia prac wydobywczych. $Z$ jednej strony mamy niezawodność i możliwość eksploatacji jako elementy charakterystyczne układu. $\mathrm{Z}$ drugiej strony, analiza podstawowych wskaźników wydajności wykorzystywana jest do obliczenia kosztów, zużycia zasobów przy wykorzystaniu sprzętu górniczego. W praktyce jednak, aspekty te modelowane są osobno, zazwyczaj przez różne zespoły badawcze w ramach kopalni. Mając to na uwadze, opracowano aplikację wspomaganą komputerowo dla generowania większej wydajności eksploatacji i prac zabezpieczających w ramach niezwykle złożonego procesu w którym sprzęt pozostaje w ciągłym ruchu, jak ma to miejsce w przypadku procesu transportu w kopalni odkrywkowej.

Słowa kluczowe: niezawodność, zabezpieczenie, aplikacja wspomagana komputerowo

* UNIVERSIDAd tÉCNICA FEDERICO SANTA MARÍA, CARRERA DE INGENIERIA EN DISEÑo DE PRODUCTOS AV ESPAÑA 1680, VALPARAÍSO, CHILE. E-Mail: christopher.nikulin@usm.cl

** CENTRO CIENTIFICO TECNOLÓGICO DE VALPARAISO, AV. ESPAÑA 1680, VALPARAÍSO, CHILE.

*** UNIVERSIDAD TÉCNICA FEDERICO SANTA MARÍA, CARRERA DE INGENIERIA CIVIL TELEMATICA, AV. ESPAÑA 1680, VALPARAÍSO, CHILE 


\section{Introduction}

The quantity of information which is transferred to decision makers has been increasing during the last years. The development of graphical systems that give better understanding and support to decision makers in the field of operational reliability, which is essential to properly manage companies' resources (Viveros et al., 2012),, even more when equipment are costly and highly complex as mining. In current literature, there are several research works displaying the main factors that directly affect the maximization of performance and economic benefit. On the one hand, those factors that converge at empirical consideration of reliability, availability and maintainability indicators (RAM). On the other hand, the traditional reliability analyses based on a logical and probabilistic modeling that contribute to improve key performance indicators (KPIs) of a system (Viveros et al., 2012), as direct influence in determining optimal operation designs (Gharbi et al., 2007; Meller \& Kim, 1996).

In this complex scenario of operational and maintenance management, computer applications programs systems could give strong support to the processes of knowledge acquisition and the decision actions carried out by the industries (Becattini et al., 2012). Nowadays in this research, Computer-Aided means supporting the decision makers allowing them to manage the complexity of technical systems by representing information beyond the statistical by itself (Becattini et al., 2012; Becatini \& Cascini, 2013). The potential benefits deriving from the implementation of computer-aided applications with modeling and real-time information can be considered as a strong support for the transfer of information as well as to better manage companies' resources. In this direction Computerized Maintenance Management Systems (CMMSs) are basically databases that allow programming and following maintenance activities according to the companies' objectives and policies (López-Campos et al., 2013). With similar view, Condition Based Maintenance (CBM) is another maintenance tool capable to monitor conditions of assets, which transfer data via web for analysis and decisions making i.e. e-CBM (López-Campos et al., 2013; Macchi et al., 2012). Usually, the maintenance tools are supported by Reliability Centered Maintenance (RCM), which facilitates the selection of the most appropriate policies to improve the physical assets to manage the consequences of their failure. The systematic studies proposed by RCM are usually based on techniques like Reliability Block Diagrams (RBDs) (Viveros et al., 2014), Failure Mode and Effect Analysis (FMEA); Reliability Block Diagram (RBD); Fault Tree Analysis (FTA), Reliability Graphics (RGs) (Muller et al., 2008), Petri Nets (PNs) (Chew et al., 2008). In this line, there are many alternatives to calculate the reliability of systems employing analytical techniques, such as Poisson, Weibull and Gamma model (Zio, 2009). Nevertheless, despite all the benefits provided by these type of analysis and computational tools (CMMS and CBM) some authors point out that many applications only consumed time and effort, because, these applications are not automated and in several cases do not provide information in an understandable terms for different decision makers. From other viewpoint, other applications do not provide real-time reliability data analysis to drive with better efficiency the operational and maintenance strategy (Gabbar et al., 2009). In this complex and dynamic scenario this article proposes a new computer-aided application suitable of providing operational and maintenance information, in specific in an open-mine, which is considered one of the most complex and resource consuming mine process. The combination operational and maintenance indicators (by considering both approach modeling and real-time) is useful to conceive a more real company strategy and also to add value to decision makers in a complex process as presented in this paper. 


\section{Background of the industrial context in Chile}

From a technology view point, Mining industry is widely viewed as an old industry with mature and stable technologies (Tilton \& Landsberg, 1999) characterized by long life cycles (Bartos, 2007). In the mining industry the lead-time to develop and commercialize new equipment is typically in the order of 7-10 years (Hilson, 2000), while investing in new technologies often implies high capital R\&D costs, because of the large scale and complexity of earthmoving equipment and the need to coordinate technology acquisition with mine-development plans (Peterson et al., 2001; Warhurst \& Bridge, 1996). As consequence maintenance plays an essential and relevant role for the mining companies at all companies' levels. Moreover, while there is a general demand for prioritizing the improvement of equipment productivity and reliability (Peterson et al., 2001), more tailored products are needed in order to optimize each phase of operation, especially from the resource consumption point of view, being the mining industry one of the most energy-intensive industries in the world (Rábago et al., 2001). This overview suggests that more research efforts are necessary in order to support the mining industry with the following: correctly supporting new technological solutions and scenarios; properly setting development priorities and manage with better efficiency the mining process. In Chile, the mining companies are one of the largest exporters of copper worldwide: world production of copper (i.e. 32\% of which corresponds to the Chilean production) (Garay et al., 2011). Several studies report about the advancements promoted by the Chilean government to increase the value proposition of this complex industrial field (Tulcanaza et al., 2001). Nowadays in Chile mining is the industry characterized by the largest investments. Specifically, its mining copper industry can be considered as a technology's receptor from different industries and countries: as a result, Chile is one of the most important buyers of mining technology in the world. However, being the mining industry an intensive-production and conservative sector, also in Chile the implementation of new technological advances takes considerable amount of time and has to face several challenges.

First, being an energy-intensive industry, the Chilean mining sector is also pressed by energy and resource shortage. Second, the accession of Chile to the OECD has also put pressure for stronger regulations in terms of sustainability indicators and accessibility to environmental information (Sustainable Development Strategies Group, 2010). Third innovative technical solutions are needed to increase workers' safety as well as the overall mine productivity. With the aim of addressing these challenges, the Chilean government has launched a variety of programs through its Economic Development Agency (CORFO). Among these, the CORFO's Mining Cluster Program is in the context of the case studies described in this paper. The aims of this program are several: increasing the investment of the auxiliary industry of goods, inputs and services that supply the local and regional mining industry; promoting the national mining cluster; encouraging technological updates of the business platform; increasing the local manufacturing capacity (CORFO, 2010). Hence, considering these needs and the strong intention of the Chilean mining industry to find new structured strategies to be more and more competitive on the worldwide market, the resulting context has been seen as very attractive and appropriate for developing and testing the authors' solution.

In Figure 1, a scheme of the mining process is provided (for a more detailed description see also Peterson et al. (2001)). The process is typically conceived by the following steps, such as: i) Drilling, blasting, cutting, and excavating; ii) Ground control; iii) Loading and hauling; iv) Material processing. Once the rock is drilled, blasted and excavated, the material is loaded onto 


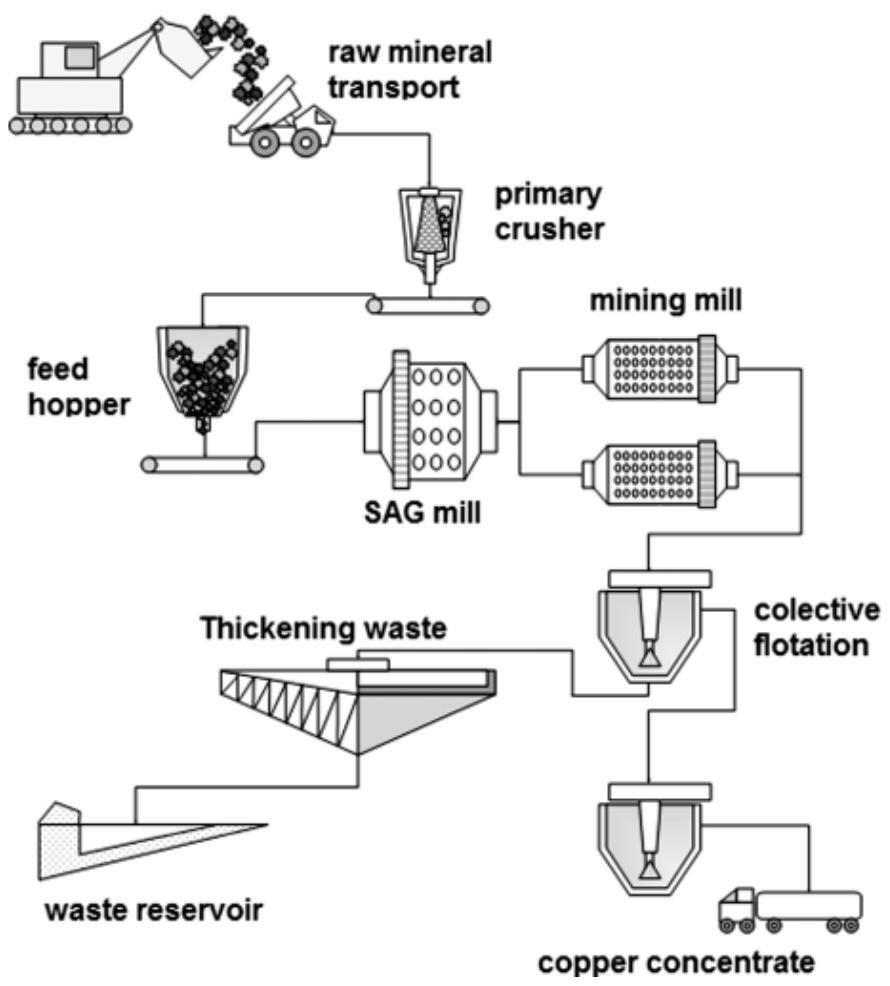

Fig. 1. A common mining process for cooper industry

haul trucks by means of large shovels. The latter ones, together with haul trucks and excavators, are typically referred as the most critical technologies for surface-mining operations and are the units around which most mining operations are designed and planned. The most significant innovations are mainly incremental and address to load capacity and reliability in order to reduce the cost per ton of material moved (Peterson et al., 2001). In addition, further challenges arise when companies demand for an increase in the size of the equipment in order to explore larger areas: this increase determines greater production and transportation costs, greater numbers of pieces that must be shipped to the site and longer field assembly times (Peterson et al., 2001). In the mining process the ore is transferred to gyratory crushers that reduce its size. This crushed ore is conveyed to the mill grinding circuit. Mining mills usually make use of grinding balls to aid the grinding process (the friction and impacts occurring between the balls and ore generate the grinding action). After the grinding phase, the ore enters flotation steel cells that enable the collection of the minerals by means of chemical actions generated by specific "collector" reagents. Besides, the maintenance activity requires manpower, resources and several days of detention: under normal operating conditions in a plant that processes $100 \mathrm{kton} /$ day, the outage cost is approximately $270^{\text {th }}$ USD per day (for further details see also S.A.P.M., (2006)). As it appears from this overview of the process, the shovel and haul trucks can be considered as two critical equipment of the process: they respectively influence its upstream and downstream activities and the overall productive capacity of the plant (in copper mining). 


\section{Approach to create a computer-aided application for modeling and monitoring operational and maintenance information in mining trucks}

When a maintenance planning is developed for mining equipment it is separately from the operational information. On the one hand, the operational planning is regularly based on the layout's changes and cost of resources which is mostly an in situ analysis. On the other hand, maintenance planning is developed based on failure times of equipment or related parts. Their corresponding limitations can create bottlenecks in the production which must be accurately evaluated and effectively corrected (Barberá et al., 2014; Goldratt, 1992). Then, the operational reliability and productivity of a system must be analyzed in a combined fashion to allow optimal exploitation of resources for achieving the set of production goals (Meller et al., 1996; Iung \& Marquez, 2006). The gap-time between these two planning cause several loses in terms of time and resources, even more when the equipment is expensive and the production intensive as in mining truck. In practice, the performance of a production line in mining industry is limited by intrinsic characteristics of each one of the equipment that contributes to the overall functioning, the most important are: i) Nominal Capacity of the machinery/stations/production equipment; ii) Reliability and Maintainability behavior; iii) Maintenance Planning; iv) Operational Restrictions; v) Setting or structure of the system. In this scenario, a computer-aided application would provide enough information in order to create a more holistic platform analysis. With this in mind, the general architecture of the computer-aided application proposed in this research is based on the structure and the information domain defined by the MIMOSA standard and its Open System Architecture for Enterprise Application Integration (OSA-EAI). The modules of the computer application are: i) RCM analysis; ii) Maintenance strategy; iii) Evaluation of maintenance strategy; iv) System planning; v) Resources management considering different KPI; vi) Assessment and continual improvement (López-Campos et al., 2013). Nevertheless, in a mining process as transport, the equipment is moving every day which implies a constant monitoring process, in specific to detect the location of the mining truck in the mine in order to establish the appropriate maintenance program. The key module of the computer-aided application is based upon CBM decision and prognosis, where diagnosis and detection is understood as isolation and identification of faults, finally, prognosis can be understood as "prediction" of failure before it occurs based on degradation. In other words, the computer-aided application is capable to support the interpretation of the CBM results, identifying the occurrence of failure modes, hazard to equipment and undesirable tendency. With this view, Tsang (1995) states that there are three important decisions to implement CBM: i) selection of the parameters to monitor, ii) inspection frequency and reliability and iii) establishing the warning limits. In order to facilitate the information RCM helps to capture this information by different types of analysis, allowing to simplify this issue.

In order to illustrate the complexity of the algorithm for analysis in this research, the computeraided application is presented in methodological steps. Six steps have been defined according to Miller's theory about capability of people to manage information (Miller, 1956); these steps are useful to understand the different analysis phases and techniques used to support decision makers.

The analytical process begins in a module, which analyzes the records of each failure mode of the equipment. A RCM analysis identifies the critical failure modes and Monitoring Parameters (MPs), this step has been divided in three sub-steps: i) Identify the critical parts of the equipment to minimize the risk; several tools and models are used to obtain the critical parts of the 


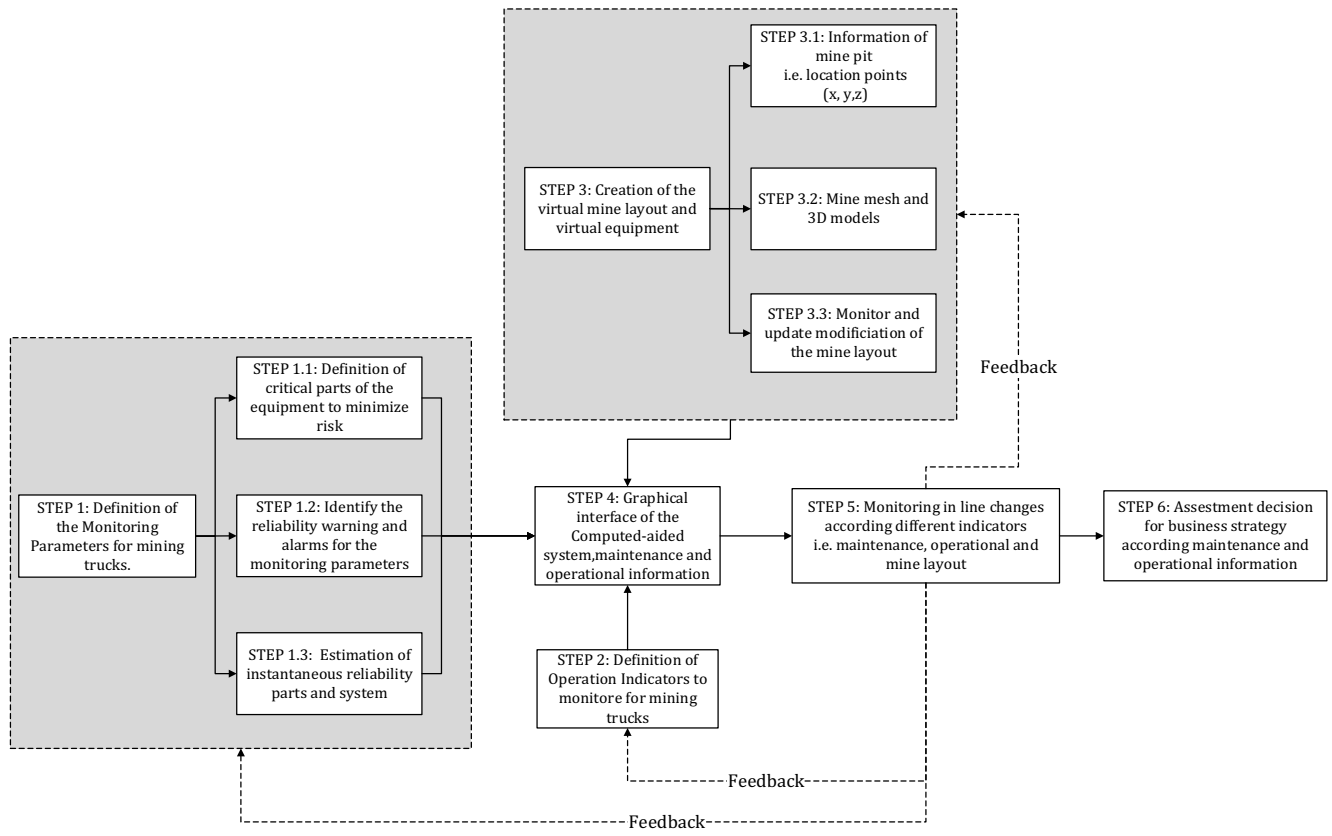

Fig. 2. Graphical representation of the steps used to create a suitable computer-aided application to monitor mining trucks

system (RCM) such as FMEA, RBD, FTA, RGs and others; ii) definition of threshold values and level of risk according to the different MPs; during this sub-step is required to define reliability and operational values of the system; iii) historical information to calculate the reliability of the equipment. In other words, reliability information should be calculated by using historical information of the system combined with criticalities of the parts. Furthermore, the definition of appropriate probability distributions is commonly used to describe the failure and repair processes of the equipment. Different types of statistical distributions are examined and their parameters are estimated. Table 1 presents the most common equation to calculate the probability of failure which are currently integrated to the computer application.

Proposed equations to calculate probability of failure of the system

\begin{tabular}{|c|c|}
\hline \hline Normal probability density function (2 parameters) & Exponential probability density function (2 parameters) \\
\hline$f(t)=\frac{1}{\sigma \sqrt{2 \pi}} \cdot e^{\left(-\frac{1}{2} \cdot\left[\frac{t-\mu}{\sigma}\right]^{2}\right)}$ & $f(t)=\lambda \cdot e^{-\lambda(t-\gamma)}$ \\
\hline Weibull probability density function (3 parameters) & Gumbel probability density function (2 parameters) \\
\hline$f(t)=\frac{\beta}{n} \cdot\left(\frac{t-\gamma}{n}\right)^{\beta-1} \cdot e^{-\left(\frac{t-\gamma}{n}\right)^{\beta}}$ & $f(t)=\frac{1}{\sigma} \cdot e^{\left(Z-e^{Z}\right)} ; Z=\frac{t-\mu}{\sigma}$ \\
\hline
\end{tabular}


Subsequently, the reliability of the equipment and related parts (i) are calculated considering the operation time, as indicated in the equation:

$$
R_{\text {system }}(t)=R_{\text {part }_{1}}(t) \cdot R_{\text {part }_{2}}(t) \cdot R_{\text {part }_{3}}(t) \ldots R_{\text {part }_{n}}(t)=\prod_{i=1}^{n} R_{\text {part }_{i}}(t)
$$

Step-2 corresponds to the definition of different Key Performance Indexes which allow to obtain information on real-time or modeling according to the current state of the equipment. These KPIs need to be simple to be understood by the end-users. Therefore, operational information would be based on the consumption of resources of the equipment such as fuel, nominal capacity and others. Then the algorithm calculates the failure probability as a function of the reliability and risk associated to the failure mode (in USD) for certain period of time related to the defined resources. With this, decision makers can compare indicators according to different scenarios in general resources terms, which are based on the condition of the different equipment.

Given that mining trucks are moving in the mine and the mine layout is changing according to the mineral extraction, these elements need to be constantly updated. With this in mind, step-3 is related to the graphical representation of the mine, mining trucks and mineral loader; during this step the mining layout needs to be created by using virtual reality models. The initial mine layout is created by data point information which establishes the real mine configuration. Moreover, further land extraction areas can be load as well. The data and information is continuously updated according to the mining truck location and extraction program. The regular actualization of data allows to keep as much as possible the reality of the extraction process. From monitoring, the mine has to be regularly updated given the changes of the layout. The critical information of the mining trucks is provided by different icons capable to simplify the information for decision makers according to the risk level. Furthermore, these previous information is putted together in the computer-aided application in order to obtain an holistic and realistic overview of the overall process supported by 3D graphs (Step-4). The graphical interface aims at monitoring the mining truck information and consumption. Moreover, the newly calculated indicators are presented in real-time in order to drive with better efficiency the operational and maintenance strategy. If it is required, the user can reconsider different process scenarios given the changes of mine layout (Step-5). Finally, the computer-aided process produces information considering "economicalmaintenance prognosis" and its innovative features rely on the new possibilities to analyze in real time the process information to assess the overall process.

\section{An application of the computer-aided application for modeling an open-mine in Chile}

The computed-aided system was conceived to drive with better efficacy the operational and maintenance strategy in a complex process where the equipment is in continuous movement such as the transportation process. In this section is presented how the computer-aided application is used to build a model to monitor the system reliability and performance. The case study includes information of an open pit mine and a mining truck float of twenty trucks, all with different historical data and information. One mining truck has been included as an example to present the procedure to transfer information to the computed-aided system. As example, the main technical specifications of the haul truck (CAT-739C) are shown in Table 2. 
Technical specification of the mining truck and critical information

\begin{tabular}{|l|l|}
\hline Engine & Cat $3526 \mathrm{~B}$ EUI \\
\hline Power & $1700[\mathrm{~kW}]$ \\
\hline Overall machine weight (Load) & $384.000[\mathrm{~kg}]$ \\
\hline $\begin{array}{l}\text { Overall machine weight (without } \\
\text { load) }\end{array}$ & $147.423[\mathrm{~kg}]$ \\
\hline Capacity & $129\left[\mathrm{~m}^{3}\right]$ \\
\hline Maximum speed & $55[\mathrm{~km} / \mathrm{h}]-$ divided in six speed \\
\hline Break surface & $89.729\left[\mathrm{~cm}^{2}\right]$ \\
\hline Fuel capacity & $3.790[$ liters $]$ \\
\hline
\end{tabular}

The logic behind the operational maintenance (functional dependency) of the process can be understood by the identification of the most critical failures in the system and related parts. Normally, there are two possible states: degradation (normal established functioning) and not degradation (failure state, preventive intervention or operational detention). With this in mind, the mining truck structure was defined by RCM by using in specific logic tree analysis, which is represented in Figure 3. Seven parts of the mining truck are connected in a simple serial setting, which implies that any single failure will cause the entire system to fail.

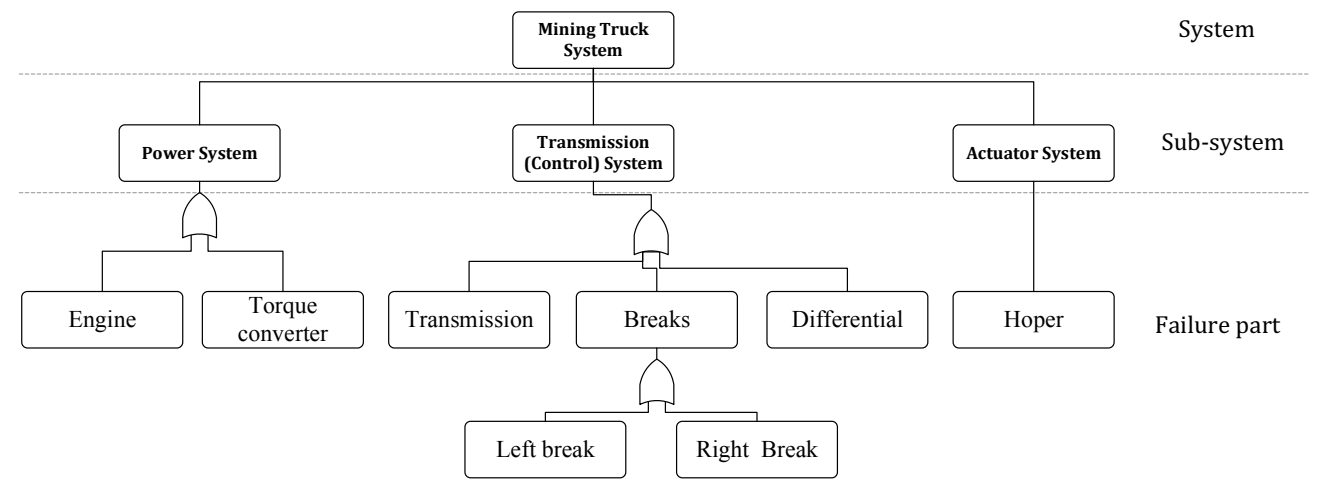

Fig. 3. Representation of mining truck and main sub-system; failure part represented by logic tree

It is important to consider two important features for the modeling process, such as: i) to model the complexity of the mining activities, it is necessary to create a "virtual" stand by each different equipment with specific parameters of failure and repair; and ii) as preliminary criteria, the repair time distribution of the "virtual" equipment must be equivalent to the repair time distribution of the actual equipment. Historical data of equipment has been used to calculate related reliability by each mining truck during the case study (i.e. twenty mining trucks). The reliability is defined as the probability that the equipment has to perform its intended function during specific period of time under stated conditions. Different probabilistic modeling corresponds to the calculation of the probabilities by each part and complete mining trucks. The selection of the probability distribution has been analyzed by using historical data of the mining truck in the last 
years. In practice, it is possible to choose and use a preferred model, or accept the distribution recommended by the software (i.e. Normal, Weibull, Exponential or Gumbel). $R(t)$ is defined as the probability of a part of the equipment without failure. In practical time, this means that the system is going to operate without failure before time (t) i.e. $R(t)=P(T>t)$. Table 3 presents the best fitting results of one of the mining trucks according to the historical data.

TABLE 3

Probability distribution associated to the mining truck parts to calculate reliability of the system

\begin{tabular}{|c|c|c|c|c|}
\hline Mining Truck(1) & Model & Parameters(1) & Parameter (2) & Parameter (3) \\
\hline Engine & Weibull & $\eta=6154.18$ & $\gamma=12454.98$ & $\beta=2.915$ \\
\hline Hoper & Weibull & $\eta=6726.97$ & $\gamma=1920.42$ & $\beta=1.935$ \\
\hline Torque converter & Gumbel & $\mu=14041.54$ & $\sigma=2733.85$ & - \\
\hline Left break & Gumbel & $\mu=15198.77$ & $\sigma=8289.00$ & - \\
\hline Right break & Gumbel & $\mu=13443.93$ & $\sigma=6307.61$ & - \\
\hline Transmission & Weibull & $\eta=8011.18$ & $\gamma=8845.45$ & $\beta=1.29$ \\
\hline Differential & Weibull & $\eta=6011.18$ & $\gamma=9714.87$ & $\beta=2.31$ \\
\hline
\end{tabular}

The information of the mining truck (1) and related parts are stored in the computer-aided application, for instance: code, type, installation date, serial, MTBF, MTTR, availability, etc. This store makes possible to review the most important equipment data and also reformulate the reliability analysis according to the maintenance of the trucks out of the mine. Consequently, if one part is reinstalled in the mining trucks, it can be updated according to the changes. In other words, the changed part can presented and updated based on the reliability curve of the new part. With this in mind, the reliability results of the mining truck (1) and its related parts are presented in Figure 4 starting all parts from $t=0$ for this case study as illustrative example.

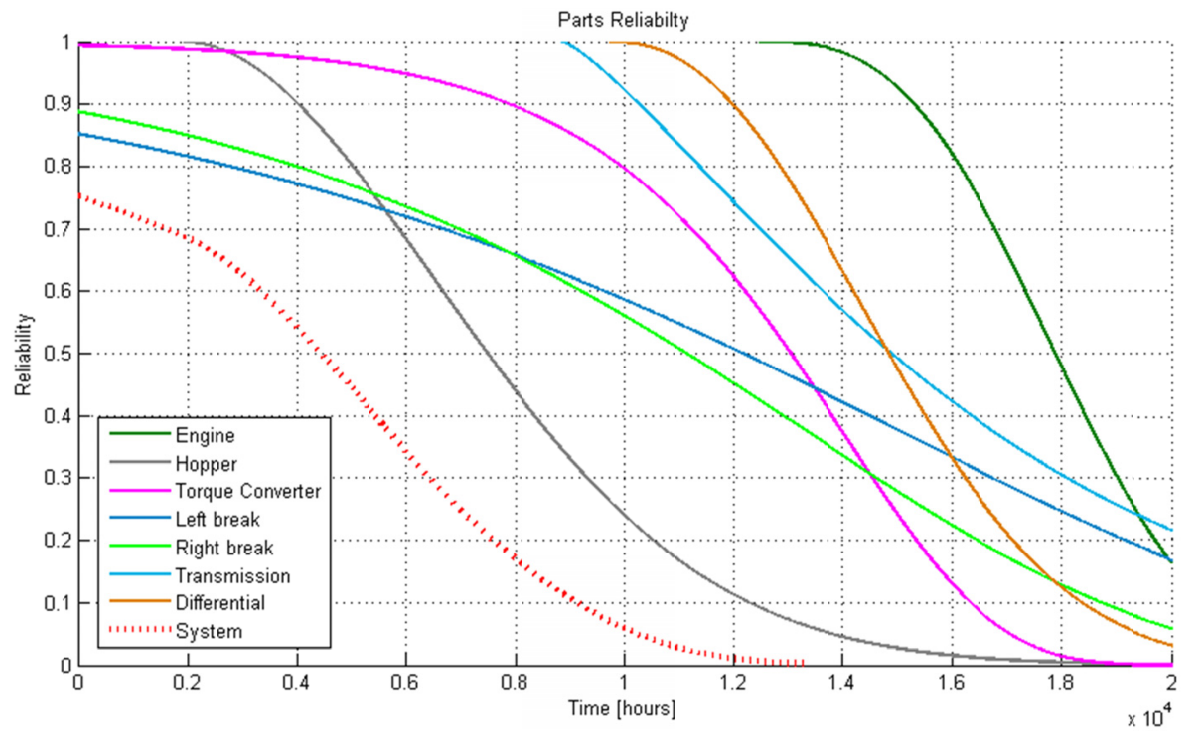

Fig. 4. Reliability of the mining truck (s) and related parts. For all the parts was considered the same time $(t=0)$ 
The over-mentioned analysis was repeated by each truck of the overall mining float (i.e. twenty trucks). In terms of operational indicators, decision makers have chosen to include in the computer system the nominal capacity of the truck, the velocity, covered distance and fuel consumption which correspond to the main indicators for the operation of the mining trucks. To simplify the case study, the risk level of the mining trucks were set up according to the reliability that the end-user is interested to be informed about, for instance: i) Lower reliability is represented by a red icon which considers reliability value under 0.5 ; ii) Medium reliability corresponds to the yellow icon which considers reliability value between 0.5 and 0.8 ; iii) Higher reliability are those with green icon, with reliability value higher than 0.8 . Furthermore, each part of the mining trucks are analyzed by the same logic when their reliability is in a specific value thresholds. In terms of virtual reality model, each element (Mine, mining trucks and shovels) were created by $3 \mathrm{D}$ models in unity 3D. Figure 5 shows the virtual model of equipment and mine.
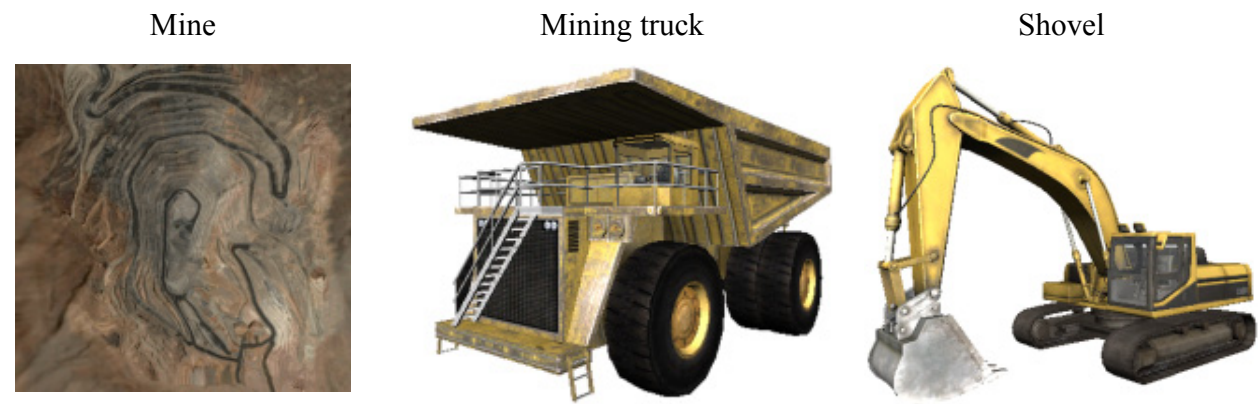

Fig. 5. Virtual models of the main elements involved in the transportation process

The different information is integrated in a virtual model capable to provide operational and reliability data to maintainers. The virtual model includes several messages according to the equipment state such as: Appropriate Operation (green color), Warning (yellow color), and Maintenance need (red color). Figure 6 shows the general modeling for the open-mine and related systems (i.e. mining trucks and shovel).

The virtual model consists in building an integral probabilistic modeling for a mining process (mining trucks), which constitutes a systematic procedure to model, simulate and sensitize the selected production process, all under innovative algorithms and friendly environment. Moreover, it can be integrated with real-time information helping the decision process. Figure 7 shows the specific information of the mining truck during its activity.

\section{Discussion}

The application of the proposed computer-aided application offers a structured and reliable step by step guide to monitor and model the dynamics of a mining process. The introduction of historical data and information allows understanding in an easy way the options and consequences of the different maintenance planning. The application is suitable to allowing at taking decisions based on statistical data and reliability of systems as a result of the entire utilization of the computer-aided application. A limitation of the proposed application relates to the domain of 


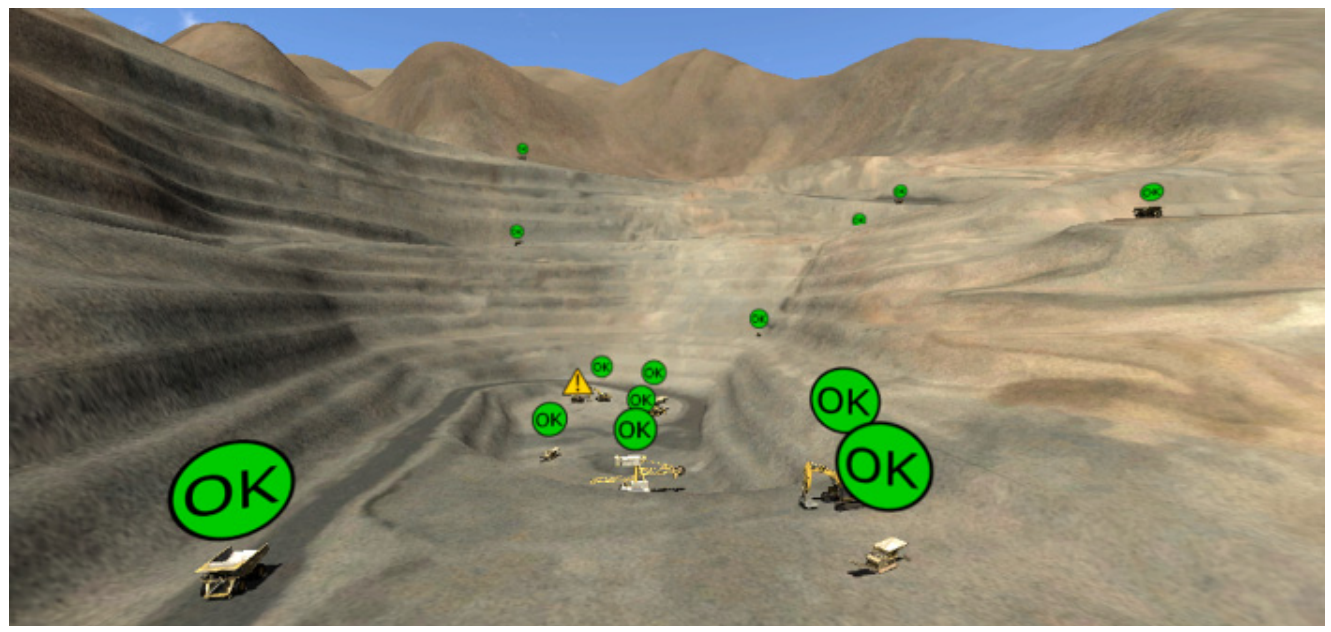

Fig. 6. Overall mine and equipment with different operational and reliability states

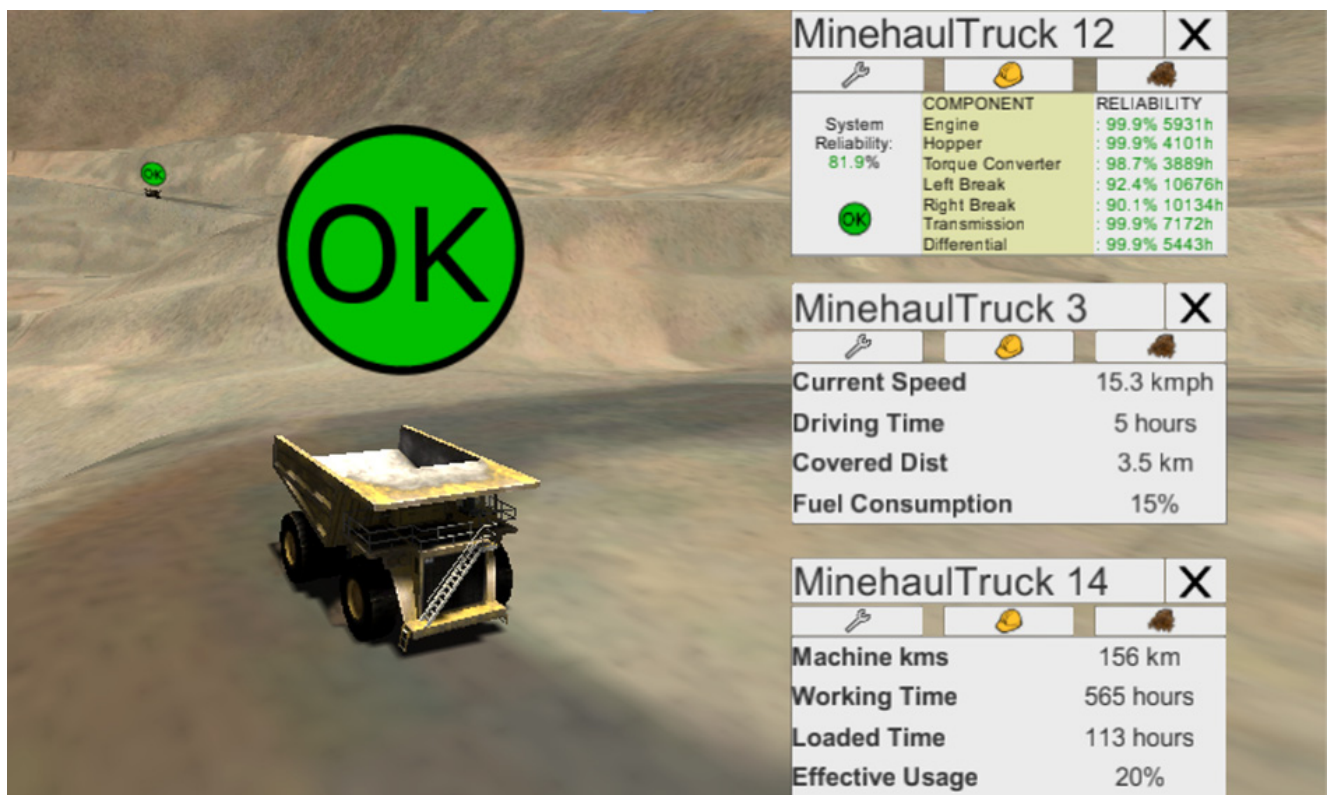

Fig. 7. Operational and reliability information of the mining truck. Colors are related to the reliability condition of the equipment part

the different tools involved in it. Even though the idea is that any person can use this application for their specific area of knowledge or expertise, the domain factor can play an important impediment in an easy and smoothly application. This is because there are different and not always well familiar terminologies, moreover, specific knowledge for mining planning is required as well. 


\section{Conclusions}

This research set as a goal the development of a computer-aided application able by one side to define and describe the situation and, by the other side, transforming this description into a model that can predict the reliability and maintainability of the system into a set of different scenarios. An important aspect of the tool, based on the concepts of RCM, is the ability of being general enough to be applied to problems and situations of different nature. The integration of the models provided by RCM: Failure Tree Analysis and Reliability system, together with modeling and scenario analysis, made possible the consolidation of this replicable and easy use computer-aided application. On the contrary, the visualization of the key performance indicators during the modeling allows the user to improve their decision by considering operational costs and resource expenses. The main result of this paper is a new modeling approach to simulate a production plant and maintenance activities, developing a case study of a real mining process (extraction), including a specific scenario with a restriction formally known as resilience. The numerical results clarify the effect of resilience in the performance results and allow preliminarily to identify critical equipment or possible bottlenecks, in terms of reliability and maintainability.

Within the advantages of the utilization of this new application, it is possible to mention obtaining measurable results in cases of general and usually ambiguous maintenance strategies. This leads us to another important point referred to the existence of a structured and guided step by step modeling, systematizing the entire process of predicting the reliability of the system. The design of this application was focused, from the beginning, to be applied in a specific 3D system, making it usable in a wide range of subjects and in different areas of knowledge as well. Due to the guided step by step model developed for mining process, the future application of the method implies an important time saving for the users of it.

With the application of the study case it was proven that the computer-aided application satisfies the proposed goal, first by setting in a systematic way the definition of modeling two different approaches as maintenance and production planning, the division into the sub-step and generation of possible scenarios, and finally by turning this description into a systemic dynamic model that can be useful to predict and planning and finally presenting a set of different system conditions, with suitable parameters according to the KPI in a complex scenario as was presented. Finally, performance analysis must be an integral part of mine engineering assessment and operational management, controlling operating plants or evaluating new designs project.

As a future research opportunity, it would be valuable the addition of indicators measuring the difference between what was predicted and what actually happened, allowing modifications in real time of the modeling system supporting as much as possible the final decision maker.

\section{Acknowledge}

The authors would like to acknowledge the Centro Cientifico Tecnologico de Valparaiso (CctVal-FB0821) for his contribution to the present research. 


\section{References}

Barberá L., Crespo A., Viveros P., Stegmaier R., 2014. A case study of GAMM (Graphical Analysis for Maintenance Management) applied to water pumps in a sewage treatment plant, Chile. Quality and Reliability Engineering International, 30(8), 1473-1480. DOI: 10.1002/qre.1549.

Bartos P.J., 2007. Is mining a high-tech industry? Investigations into innovation and productivity advance. Resources Policy, 3, 149-158. DOI: 10.1016/j.resourpol.2007.07.001.

Becattini N., Cascini G., 2013. Mapping Causal Relationships and Conflicts among Design Parameters and System Requirements. Computer-Aided Design and Applications, 10(4), 643-662. DOI: 10.3722/cadaps.2013.643-662.

Becattini N., Borgianni Y., Cascini G., Rotini F., 2012. Model and algorithm for computer-aided inventive problem analysis. Computer-Aided Design, 44(10),961-986. DOI: 10.1016/j.cad.2011.02.013.

Chew S.P., Dunnett S.J., Andrews J.D., 2008. Phased mission modelling of systems with maintenance-free operating periods using simulated Petri nets. Reliability Engineering \& System Safety, 93(7), 980-994. DOI: 10.1016/j.ress.2007.06.001

CORFO, Mining Cluster in Chile-2010, available on-line at www.unido.org, last accessed January 2015.

Gabbar H.A., Yamashita H., Suzuki K., Shimada Y., 2009. Computer-aided RCM-based plant maintenance management system. Robotics and Computer-Integrated Manufacturing, 19(5), 449-458. DOI: 10.1016/S0736-5845(03)00031-0.

Garay V., Schwarz S., Donoso F., 2012. Informe Tendencias Mercado del Cobre-Balance 2011 y Perspectivas 2012-2013. COLCHICO-Dirección de estudios y politicas públicas.

Gharbi A., Kenné J.P., Beit M., 2007. Optimal safety stocks and preventive maintenance periods in unreliable manufacturing systems. International Journal of Production Economics, 10(2), 422-434. DOI: 10.1016/j.ijpe.2006.09.018.

Goldratt E., 1992. The goal: a process of ongoing improvement. North River Press, Great Barrington, Massachusetts. ISBN-10: 0566074176.

Hilson G., 2000. Barriers to implementing cleaner technologies and cleaner production (CP) practices in the mining industry: a case study of the Americas. Minerals Engineering, 13(7), 699-717. DOI: 10.1016/S0892-6875(00)00055-8.

Iung B., Marquez A.C., 2006. Special issue on e-maintenance. Computers in Industry, 57(6): 473-475. DOI: 10.1016/j. compind.2006.02.016.

Jardine A.K., Lin D., Banjevic D., 2006. A review on machinery diagnostics and prognostics implementing condition-based maintenance. Mechanical systems and signal processing, 20(7), 1483-1510. DOI: 10.1016/j.ymssp.2005.09.012.

Kahn J., Klemme-Wolf H. Overview of MIMOSA and the open system architecture for enterprise application integration. [In:] Proc. of COMADEM, p. 661-670.

López-Campos M.A., Márquez A.C., Fernández J.F. G., 2013. Modelling using UML and BPMN the integration of open reliability, maintenance and condition monitoring management systems: An application in an electric transformer system. Computers in Industry, 64(5), 524-542. DOI: 10.1016/j.compind.2013.02.010.

Macchi M., Kristjanpoller F., Garetti M., Arata A., Fumagalli L., 2012. Introducing buffer inventories in the RBD analysis of process production systems. Reliability Engineering \& System Safety, 104, 84-95. DOI: 10.1016/j.ress.2012.03.015.

Meller R.D., Kim D.S., 1996. The impact of preventive maintenance on system cost and buffer size. European Journal of Operational Research, 95(3), 577-591. DOI: 10.1016/0377-2217(95)00313-4.

Miller G.A., 1956. The magical number seven, plus or minus two: some limits on our capacity for processing information. Psychological review, 63(2), 81-97.

Muller A., Marquez A.C., Iung B., 2008. On the concept of e-maintenance: Review and current research. Reliability Engineering \& System Safety, 93(8): 1165-1187. DOI: 10.1016/j.ress.2007.08.006.

Peterson D.J., LaTourrette T., Bartis J.T., 2001. New Forces at Work in Mining Industry: Views of Critical Technologies. Monograph/Reports, available on-line at www.rand.org, last accessed January 2015.

Rábago K.R., Lovins A.B., Feiler T.E., 2001. Energy and sustainable development in the mining and minerals industries. IIED report, available on line at www.iied.org, last accessed January 2015.

S.A. P. M., 2006. Manual General de Minería y Metalurgia. Antofagasta: Portal Minero Ediciones (In Spanish). ISBN: 9568514015.

Sustainable Development Strategies Group, Report-2010: current issues in the Chilean mining sector, available on-line at www.sdsg.org, last accessed January 2015. 
Tilton J.E., Landsberg H.H., 1999. Innovation, productivity growth, and the survival of the US copper industry. Productivity in Natural Resource Industries; Improvement through Innovation, 109-139.

Tsang A.H., 1995. Condition-based maintenance: tools and decision making. Journal of Quality in Maintenance Engineering, 1(3), 3-17. DOI: 10.1108/13552519510096350.

Tulcanaza E., Ferguson G., 2001. The value of information: a guide to the strategic development of projects founded on mineral resource categorization. Transactions of the institution of mining and metallurgy section b-applied earth science; 110, b126-b135. DOI: 10.1179/aes.2001.110.3.126

Viveros P., Zio E., Kristjanpoller F., Arata A., 2012. Integrated system reliability and productive capacity analysis of a production line. A case study for a Chilean mining process. Proc. IMechE, Part O: J. Risk Reliability, 226(3), 305-317, DOI: 10.1177/1748006X11408675.

Viveros P., Crespo A., Kristjanpoller F., Stegmaier R., Johns E., Gonzalez-Prida V., 2014. Probabilistic performance assessment for crushing system. A case study for a mining process. Probabilistic Safety Assessment and Management PSAM 12, June, Honolulu, Hawaii.

Warhurst A. Bridge G,. 1996. Improving environmental performance through innovation: recent trends in the mining industry. Minerals Engineering, 9(9), 907-921. DOI: 10.1016/0892-6875(96)00083-0.

Zio E., 2009. Reliability engineering: Old problems and new challenges. Reliability Engineering \& System Safety, 94(2), 125-141. DOI: 10.1016/j.ress.2008.06.002. 